\title{
MENGEMBANGKAN JIWA KEAGAMAAN ANAK (Perspektif Pendidikan Islam dan Perkembangan Anak Usia Dini)
}

\author{
Triana Rosalina Noor
}

STAI An Najah Indonesia Mandiri Sidoarjo

trianasuprayoga@gmail.com

\section{Article History:}

Received : 14-08-2020

Revised : 27-08-2020

Accepted : 23-09-2020

\begin{abstract}
The first five years of development are a very important period in child development, because in this range, children experience optimal cognitive development. At that time, it became the right range to develop a child's religious spirit. The research method used is literature study, namely conducting a process of reviewing books, existing theories to be linked with the topic of developing the religious spirit of early childhood. The results of this study indicate that in the process of developing the religious and moral spirit of early childhood, they must consider the stages of children's development, both psychological and physical development. The development of a religious spirit can be carried out in a tangible form through participation in daily religious activities, so that children get firsthand real experiences taught by parents or teachers. Methods of delivery can be through lectures, games, stories, role playing, habituation and exemplary. Therefore, both parents and teachers need to provide stimulation so that their children can respond quickly to learning religious concepts in the hope that they can develop their sense of diversity.
\end{abstract}

Keyword: Islamic Education, Early Childhood, religious soul

\section{Pendahuluan}

Mengacu pada Undang-undang Nomor 35 tahun 2014 tentang Perubahan Atas Undang-undang Nomor 23 tahun 2002 tentang Perlindungan Anak bahwa anak adalah bagian yang tidak terpisahkan dari keberlangsungan hidup manusia dan keberlangsungan sebuah bangsa dan negara. Agar kelak mampu bertanggung jawab dalam keberlangsungan bangsa dan negara, setiap Anak perlu mendapat kesempatan yang seluas-luasnya untuk tumbuh dan berkembang secara optimal, baik fisik, mental, maupun sosial.

Anak-anak adalah pribadi yang unik dan melalui keunikannya inilah orang tua sudah selayaknya untuk bisa bersikap lebih toleran dengan segala perilaku yang diperbuat seorang anak, mulai tingkah yang menggemaskan sampai menjengkelkan. Meskipun demikian, bagaimanapun tingkah mereka tetap saja perhatian orang tua yang 
penuh cinta sangat dibutuhkan untuk memberikan asuhan dan pendampingan dalam bentuk memberikan pendidikan yang terbaik. Melalui pendampingan dari orang tua akan membantu memaksimalkan perkembangan dan pendidikan anak sesuai dengan kemampuan maupun kesempatan yang mereka miliki. ${ }^{1}$

Adapun pendidikan yang penting untuk diajarkan kepada anak adalah tidak hanya terkait dengan pengetahuan di sekolah namun wawasan yang luas atas banyak hal. Hal ini dikarenakan pendidikan yang diberikan kepada anak merupakan investasi masa depan yang diyakini dapat memperbaiki kehidupan suatu bangsa kelak. Salah satunya adalah pendidikan yang terkait agama dan moral. Pendidikan agama dan moral itu penting untuk diajarkan dan dibiasakan sejak anak masih dalam tahap usia dini mengingat tingginya tingkat tingginya kasus kenakalan remaja dewasa ini ${ }^{2}$ sehingga anak usia dini menjadi bagian penting yang sangat berperan dalam melakukan antisipasi dan memberikan konstribusinya mewujudkan bangsa yang bermoral dan bermartabat kedepannya. Hal ini senada dengan firman Allah:

Artinya: "Hai orang-orang yang beriman, peliharalah dirimu dan keluargamu dari api neraka yang bahan bakarnya adalah manusia dan batu; penjaganya malaikat-malaikat yang kasar, yang keras, yang tidak mendurhakai Allah terhadap apa yang diperintahkan-Nya kepada mereka dan selalu mengerjakan apa yang diperintahkan.(At Tahrim: 6)

Usia dini merupakan masa keemasaan (golden age) yang hanya terjadi satu kali dalam perkembangan kehidupan manusia, terlebih pada lima tahun pertama. Hal ini dikarenakan pada rentang tersebut $50 \%$ potensi kognitif anak usia dini berkembang dan mulai terbentuk dengan baik dan kognitif merupakan salah satu komponen utama yang akan menentukan keseluruhan potensi perkembangan manusia pada nantinya. Pada rentang inilah, anak sangat cepat dalam menyerap informasi yang didapat dari lingkungannya, salah satunya adalah informasi terkait konteks agama. ${ }^{3}$ Manusia dan lingkungan saling berinteraksi antara satu dengan lainnya. ${ }^{4}$

Dalam rangka mencapai keberhasilan pembentukan kepribadian anak agar mampu terwarnai dengan nilai- nilai agama maka dibutuhkan stimulasi dan fasilitas yang tepat. Stimulasi bisa datang dari orang tua, sekolah ataupun masyarakat. Stimulasi yang tepat tersebut sanat berguna bagi pengembangan nilai-nilai moral dan agama anak usia dini. Seorang anak usia dini dapat belajar membedakan perilaku yang baik dan buruk, benar dan salah, serta terbiasa menjalankan ajaran agama sesuai dengan tingkat pertumbuhan dan perkembangannya. Harapannya perilaku amoral dan sikap bertentangan dengan

${ }^{1}$ Rahminur Diadha, "Keterlibatan Orang Tua Dalam Pendidikan Anak Usia Dini Di Taman KanakKanak," Edusentris 2, no. 1 (2015): 61-71.

2 Endang Mei Yunalia and Arif Nurma Nurma Etika, "Analisis Perilaku Agresif Pada Remaja Di Sekolah Menengah Pertama," JHeS (Journal of Health Studies) 4, no. 1 (2020): 40

3 Ainna Amalia FN et al., Metode Pengembangan Kognitif Anak Usia Dini (Surabaya: UIN Sunan Ampel Press, 2018). 90

4 Triana Rosalina Noor, "Analisis Desain Fasilitas Umum Bagi Penyandang Disabilitas (Sebuah Analisis Psikologi Lingkungan)," Journal An-Nafs: Kajian Penelitian Psikologi 2, no. 2 (2017): 134 
norma agama tidak muncul pada diri anak. ${ }^{5}$ Anak akan memahami dan mengamalkan ajaran agama dan menjadikannya sebagai pandangan hidup. ${ }^{6}$

Konsep agama diberikan kepada anak diberikan dalam bentuk simbol nyata. ${ }^{7}$ Mengajarkan dan mengembangkan jiwa keagamaan pada anak bisa dilakukan melalui pembiasaan, pengajaran dan teladan. ${ }^{8}$ Keagamaan seseorang terbentuk oleh beberapa pra kondisi seperti kehidupan keagamaan dalam keluarga, pengalaman spiritual individu, teman sebaya, organisasi/ perkumpulan rujukan, role model, informasi yang diterima dari lingkungan dan kondisi lainnya. ${ }^{9}$ Khusus ada penanaman nilai-nilai agama pada anak harus memperhatikan beberapa faktor seperti usia, fisik, dan psikis anak itu sendiri. Jiwa dan rasa keagamaan anak akan tumbuh dan berkembang seiring dengan perkembangan fisik dan psikisnya. Perhatian anak terhadap nilai-nilai dan pemahaman agama akan muncul manakala mereka selalu melihat dan terlibat dalam upacaraupacara keagamaan, dekorasi dan keindahan rumah ibadah, rutinitas, ritual orang tua dan lingkungan sekitar ketika menjalankan ibadah. ${ }^{10}$ Anak pada akhirnya akan belajar dari pengalaman langsung karena dilibatkan secara aktif dalam seluruh kegiatan keagamaan yang diikuti. ${ }^{11}$ Melalui cara-cara tersebutlah diyakini akan membentuk karakter dan jiwa agamis pada anak sehingga terwujud akhlaqul karimah yang tercermin melalui memiliki sosialisasi yang baik dengan lingkungan, taat dan disiplin dalam beribadah. Disiplin dalam ibadah ini akan membentuk karakter patuh pada aturan dan ajaran agama yang dianutnya. ${ }^{12}$

Metode penelitian yang digunakan dalam penulisan artikel ilmiah ini adalah menggunakan penelitian kepustakaan. Peneliti menelaah teori-teori, konsep-konsep, definisi, pengertian tentang variabel-variabel yang diteliti untuk dicari keterkaitannya. Peneliti akan mencoba menghubung-kaitkan antara konsep-konsep yang ada, mana yang menjadi sebab dan dampak. ${ }^{13}$

\section{Hakikat Anak Perspektif Pendidikan Islam}

Berdasarkan pandangan pendidikan Islam yang akan memperlakukan anak didiknya secara adil, bijaksana bahkan penuh dengan keteladanan maka bisa ditebak kalau metode pendidikan yang akan digunakan sangatah manusiawi. Hakikat wujudnya

5 Rizki Ananda, "Implementasi Nilai-Nilai Moral Dan Agama Pada Anak Usia Dini," Jurnal Obsesi: Jurnal Pendidikan Anak Usia Dini 1, no. 1 (2017): 21

6 Zakiah Daradjat, Ilmu Pendidikan Islam (Jakarta: PT. Bumi Aksara, 2018). 86

7 Triana Rosalina Noor, "Remaja Dan Pemahaman Agama," Vicratina: Jurnal Pendidikan Islam 3, no. 2 (2019): 68

8 Triana Rosalina Noor, "Upaya Guru Dalam Menanamkan Nilai Agama Di KB Al Muslim Surabaya," EDUSIANA: Jurnal Manajemen dan Pendidikan Islam 4, no. 1 (2017): 70

9 Triana Rosalina Noor, "Orientasi Aktivitas Dan Kelompok Keagamaan Mahasiswa," in Prosiding Seminar Nasional Islam Moderat, vol. 1 (Jombang: Unwaha, 2018), 158

10 Muhammad Ali Saputra, "Penanaman Nilai-Nilai Agama Pada Anak Usia Dini Di RA DDI Addariyah Kota Palopo," Al-Qalam 20, no. 2 (2016): 199

11 Triana Rosalina Noor, "Manajemen Pendidikan Anak Melalui Program Outbound Di TK Al Muslim Surabaya," SELING: Jurnal Program Studi PGRA 3, no. 2 (2017): 64-75. 65

12 Triana Rosalina Noor and Erwin Astutik, "RODA (Rotating Education Game) Sebagai Media Pembelajaran Untuk Menanamkan Sikap Disiplin Pada Anak Usia Dini," AS-SABIQUN 1, no. 2 (2019): 3

${ }^{13}$ Didin Fatihudin, Metode Penelitian (Sidoarjo: Zifatama Publisher, 2015). 45 
adalah manusia berkembang dipengaruhi oleh lingkungan dan pembawaannya. ${ }^{14}$ Menurut Islam, adanya faktor pembawaan ini sebagaimana sabda Rasulullah SAW yakni:

"Tiap anak yang dilahirkan membawa fitrah, ayah ibunyalah yang akan menjadikannya Yahudi, Nasrani atau Majusi (HR. Bukhari dan Muslim).

Berdasarkan hadis tersebut, manusia lahir akan membawa kemampuankemampuannya masing-masing yang pada nantinya akan menentukan perkembangan seseorang. Secara garis besar, manusia atau anak yang dilahirkan akan membawa kecenderungan baik dan kecenderungan menjadi orang yang jahat, dan kecenderungan beragama merupakan kecenderungan ke arah yang baik. ${ }^{15}$ Pada dasarnya manusia itu sejak lahir berkecenderungan untuk beriman dan ingin beragama. ${ }^{16}$ Keinginan tersebut akan meningkat seiring dengan perkembangan taraf pemikirannya ke arah yang lebih baik. Hal ini dikarenakan agama diperlukan oleh seorang manusia sebagai kerangka orientasi untuk penyempurnaan kehidupannya. ${ }^{17}$

Tujuan pendidikan Islam yang paling utama ialah beribadah kepada Allah dan kesempurnaan insan yang tujuannya kebahagiaan dunia akhirat sedangkan fungsi pendidikan agama bagi anak adalah membentuk manusia yang beriman dan bertaqwa kepada Allah SWT, mempunyai akhlak yang luhur, berilmu pengetahuan dan memilik keterampilan yang dapat disalurkan. Agama benar-benar berfungsi sebagai pengendalian kepribadian dalam hidupnya dikemudian hari. Pendidikan agama harus diberikan sejak dini agar terbiasa melakukan ibadah dan menjalankan ajaran-ajaran Islam dengan kesadaran sendiri.

Zakiah Dradjat mengemukakan bahwa manusia membutuhkan hal selain kebutuhan rohani dan jasmani agar dirinya tidak tertekan. Lingkungan harus memberikan dukungan dan pendidikan yang baik pula untuk kebutuhan-kebutuhan tersebut, yakni : 18

1. Kebutuhan akan kasih sayang. Kebutuhan ini merupakan kebutuhan untuk mendapatkan dari orang lain, sehingga jika tidak terpenuhi maka akan menggangu keseimbangan psikis seseorang

2. Kebutuhan akan rasa aman. Kebutuhan ini merupakan kebutuhan yang mendorong seseorang untuk mendapatkan perlindungan. Bagi seorang anak usia dini, perlindungan ini bisa berasal dari orang tua dan jika tidak terpenuhi maka anak tersebut akan merasakan ketidaknyamanan secara emosional

3. Kebutuhan akan harga diri. Anak usia dini juga membutuhkan penghargaan dari orang lain. Kebutuhan ini bersifat individual dan jika tidak terpenuhi maka anak mungkin akan menjadi rendah diri dan mengucilkan diri dari lingkungan.

4. Kebutuhan akan rasa bebas. perkembangan anak usia dini adalah sebuah rentang yang memberikan ruang pada anak untuk berekspresi seluas-luasnya. Anak

${ }^{14}$ Ahmad Tafsir, Ilmu Pendidikan Dalam Perspektif Islam (Bandung: PT. Remaja Rosdakarya, 2014).

16 Ibid. 35

17 Muhammad Idrus, “Makna Agama Dan Budaya Bagi Orang Jawa,” Unisia 30, no. 66 (2007): 398

18 Jalaluddin Jalaluddin, Psikologi Agama (Jakarta: PT. RajaGrafindo Persada, 2012). 60 
memiliki masa bermain sesuai tahap perkembangannya. Artinya jika kebebasan anak ini tidak diberikan, maka akan terjadi pergolakan pada batinnya sehingga mengganggu pertumbuhan psikis anak.

5. Kebutuhan akan kesuksesan. Bagi anak usia dini, kesuksesan yang dimaknai adalah suatu hal yang tidak sekompleks orang dewasa. Adanya keberhasilan dalam mengerjakan tugas sederhana adalah suatu bentuk kesuksesan yang perlu diapresiasi oleh sekitarnya.

6. Kebutuhan akan rasa ingin tahu. Pada masa usia dini, rasa keingintahuan yang dimiliki sangatlah besar, sehingga bimbingan dari orang tua sangat diperlukan untuk mengarahkan keingintahuannya tersebut agar terarah dan sesuai norma. ${ }^{19}$

\section{Pendidikan Keagamaan dan Moral Pada Anak dalam Islam}

Tanggung jawab pendidikan diselenggarakan bersamaan dengan adanya kewajiban mendidik. Secara umum mendidik adalah membantu anak untuk bisa mengembangkan potensi-potensi yang dimilikinya melalui internalisasi nilai-nilai yang baik. Bantuan atau bimbingan itu dilakukan dalam situasi formal sampai dengan informal, mulai institusi pendidikan sammpai dengan keluarga dan masyarakat. Orang tua menanamankan jiwa keagamaan keluarga dan rumah tangga dan guru pada lingkungan sekolah dan masyarakat. ${ }^{20}$

Orang tua merupakan pendidik utama dan pertama dalam hal penanaman keagamaan dan moral anak karena oleh karena merekalah pihak yang pertama kali memberikan pendidikan sebelum pada akhirnya anak akan masuk ke lingkungan pendidikan formal. Orang tua mempunyai peranan penting dalam mendidik anakanaknya terutama dalam menanamkan nilai-nilai Islam kepada anaknya. Anak-anak diawal usianya, mereka dibentuk dan didik sejak dari awal. Dalam Islam orang tua bertanggung jawab untuk memberikan pendidikan sesuai dengan fitrahnya, yaitu keimanan kepada Allah SWT. ${ }^{21}$ Fitrah ini merupakan konsep dasar operasional dari proses penciptaan manusia. Di dalamnya terkandung kekuatan potensial untuk tumbuh dan berkembang secara maksimal dan mengarahkannya untuk mencapai tujuan penciptaannya. Konsep dasar keimanan ini telah digambarkan dalam Al-Quran ketika Luqmanul Hakim memberikan pendidikan dasar terhadap anaknya sebagaimana firman Allah SWT :

Dan (ingatlah) ketika Luqman berkata kepada anaknya, ketika dia memberi pelajaran kepadanya, "Wahai anakku! Janganlah kamu mempersekutukan Allah, sesungguhnya mempersekutukan (Allah) adalah benar-benar kezaliman yang besar". (QS. Luqman 13).

19 Elfan Fanhas F Kh and Gina Nurazizah Mukhlis, "Pendidikan Karakter Untuk Anak Usia Dini Menurut QS Lukman: 13-19," PEDAGOGI: Jurnal Anak Usia Dini Dan Pendidikan Anak Usia Dini 3, no. 3a (2017): 50

20 Daradjat, Ilmu Pendidikan Islam. 35

21 Rafieqah Nalar Rizky and Moulita Moulita, "PENANAMAN NILAI-NILAI ISLAM MELALUI KOMUNIKASI INTERPERSONAL ORANG TUA PADA ANAK," Jurnal Interaksi: Jurnal Ilmu Komunikasi 1, no. 2 (2017): 208 
Orang tua merupakan pendidik utama dan pertama dalam hal penanaman keagamaan dan moral anak karena oleh karena merekalah pihak yang pertama kali memberikan pendidikan sebelum pada akhirnya anak akan masuk ke lingkungan pendidikan formal. Orang tua yang memiliki anak yang masih dalam rentang usia dini sudah semestinya memperkenalkan syariat Islam. Orang tua disamping memberikan arahan juga harus memberikan contoh-contoh tauladan yang baik kepada mereka dengan memanfaatkan sifat peniruan yang ada pada anak, karena sifat peniruan itulah merupakan cara belajarnya dan dapat membentuk pribadinya. ${ }^{22}$

Selain itu sosok guru juga memiliki andil yang besar dalam penanaman keagamaan pada anak usia dini. Guru juga memikul sebagian dari beban orang tua untuk mendidik anak dengan ajaran yang benar. Sosok guru yang bisa mendukung pendidikan yang Islami adalah sebagai sosok yang bisa ditempatkan sebagai teladan bagi anak. Guru sudah sepantasnya selalu berusaha untuk semaksimal mungkin menempatkan dirinya sebagai model yang bisa menjadi panutan.

Adapun konsep pendidik dalam sistem pendidikan Islam adalah sebagai murobbi, muallim dan muaddib. Murabbi adalah menggambarkan fungsi dan perannya sebagai pengayom, pembimbing, pengarah, pemelihara yang didasarkan pada tanggung jawab dan rasa kasih sayang. Pendidik sebagai muallim adalah mengacu kepada fungsi dan perannya sebagai pemberi informasi dan pembentuk keterampilan serta kombinasi antara keduanya. Pemebri informasi akan didentikkan dengan pemberian informasi atas ilmu pengetahuan dan pembentuk keterampilan diidentikkan dengan penguasaan teknologi. Selanjutnya konsep muaddib akan menguatkan fungsi dan peran pendidik sebagai pembentuk sikap dan perilaku yang didasarkan pada nilai akhlak yang baik. ${ }^{23}$

Berdasarkan konsep murabbi, muallim dan murabbi yang disematkan kepada seorang pendidik maka sudah jelaslah bahwa seorang pendidik harus bisa menampilkan diri sebagai orang tua pada anak didiknya dan juga sebagai panutan mereka dalam berperilaku dalam kesehariannya. Secara umum, konsep pendidik ini mengandung arti bahwa pada dasarnya setiap orang bisa menempatkan dirinya sebagai pendidik. Orang tua dalam lingkungan keluarga akan menempatkakn dirinya sebagai pendidik secara kodrati orang tua kandung. Adapun pendidik yang berada dalam sebuah institusi pendidikan akan juga dituntut untuk menjalankan fungsinya sebagai pendidik formal. Dan untuk selanjutnya konsep pendidik juga berlaku untuk pemimpin ataupun tokoh pemimpin ataupun tokoh panutan masyarakat yang memiliki peluang untuk memberikan pendidikan kepada masyarakat umum secara luas.

Selain itu metode yang digunakan juga menjadi hal yang penting dalam penanaman dan pengembangan jiwa keagamaan seoarang aka usia dini. Metode pendidikan merupakan alur ataupun jalan yang harus digunakan agar pencapaian tujuan pendidikan bisa tercapai. Terkait dengan pendidikan Islam maka metode pendidikan yang dimaksud adalah metode pendidikan yang merujuk pada Al-Quran.

22 Mohamad Syakur Rahman, "PERAN ORANG TUA DALAM PENANAMAN NILAI-NILAI ISLAM," Jurnal Ilmiah Iqra' 12, no. 1 (2018): 28

${ }^{23}$ Jalaluddin Jalaluddin, Pendidikan Islam :Pendekatan Sistem Dan Proses (Jakarta: PT. RajaGrafindo Persada, 2016). 150 


\section{Perkembangan Anak Usia Dini: Makna Nilai, Moral dan Agama bagi Anak}

Nilai adalah suatu hal yang penting untuk ditanamkan dalam rangka mengembangkan jiwa keagamaan anak. Menurut Spranger, nilai diartikan sebagai suatu tatanan yang dijadikan panduan oleh seorang anak untuk menimbang dan memilih alternatif keputusan dalam situasi sosial tertentu. Meskipun menempatkan situasi sosial sebagai dimensi nilai dalam kepribadian seorang anak, menandakan bahwa Spranger mengakui adanya kekuatan individual yang dikenal dengan istilah "ruh subyektif" serta kekuatan situasi sosial melalui unsur nilai budaya yang dikenal sebagai "ruh obyektif" saling terkait antara satu dengan yang lain. Dari sudut pandang Spranger, keberadaan kekuatan individual dan kekuatan situasi sosial memiliki fungsi yang sangat penting karena nilai budaya hanya akan berkembang dan berkembang dan bertaham jika didukung oleh kekuatan individual anak dalam mencermatinya. ${ }^{24}$

Dengan demikian, nilai merupakan suatu hal yang dipercaya kebenarannya oleh seorang anak dan akan mendorong anak tersebut untuk mewujudkannya. Oleh karena nilai merupakan standar konseptual yang relatif stabil baik secara implisit atau eksplisit maka bimbingan dari orang tua atas anak sangat diperlukan. Hal ini bertujuan agar anak dapat menentukan tujuan yang ingin dicapai dan bisa melakukan aktivitas sesuai dengan konsep lingkungan yang ada guna memenuhi kebutuhan psikologisnya.

Istilah moral berasal dari kata Latin "mores", yang artinya tata cara dalam kehidupan, adat istiadat ataupun kebiasaan. Moral pada anak merupakan rangkaian nilai tentang bagaimana anak berperilaku atas suatu ketentuan yang harus dipenuhi moral merupakan sebuah kaidah yang akan mengatur anak dalam kaitannya dengan lingkungan sosialnya. Perilaku moral anak bisa terlihat dari kehidupannya yang penuh keteraturan, ketertiban dan keharmonisan. ${ }^{25}$

Tokoh yang paling dikenal dalam kaitannya dengan perkembangan moral adalah Lawrence. E. Kohlberg. Pada sebuah penelitian yang dilakukannya tentang pertimbangan moral pada anak menunjukkan bahwa segala tindakan dan perilaku yang dilakukan anak akan mengacu pada struktur mental anak itu sendiri. Artinya tafsiran tentang sebuah konsep akan menyesuaikan tingkat perkembangan atau struktur moral masing-masing individu. Semakin seseorang berada pada perkembangan yang matang maka struktur moralnya pun akan relatif mengikuti dan begitu pula sebaliknya. ${ }^{26}$ Moral anak akan berkembang melalui interaksi sosial dan semakin tinggi tahap moral seorang anak maka akan semakin mantap pula perkembangan moralnya dan akan menjadi lebih bertanggung jawab. ${ }^{27}$

Selaras dengan sebuah konsep nilai dan moral yang ada pada anak, maka bisa dilihat kalau banyak sekali persoalan yang terlihat pada perilaku anak yang berkaitan dengan kondisi psikologis yang juga beragam pada anak. Maka muncullah sebuah persoalan tentang bagaimana sebenarnya "rasa agama" dalam diri anak beserta bagaimana proses perkembangannya.

\footnotetext{
24 Mohammad Asrori, Psikologi Pembelajaran (Bandung: CV . Wacana Prima, 2009). 153

25 Elizabeth B Hurlock, Perkembangan Anak Jilid 2 (Jakarta: Erlangga, 1999). 74

${ }^{26}$ Asrori, Psikologi Pembelajaran. 155

27 Desmita Desmita, Psikologi Perkembangan (Bandung: PT. Remaja Rosdakarya, 2015). 151
} 
Perlu dipahami dan disadari bahwa anak bukanlah miniatur orang dewasa, namun ana adalah seorang manusia yang unik dan orisinil yang telah lahir ke dunia. Terkait dengan konteks suatu agama, perlu dipahami kembali juga bahwa pemahaman agama pada anak berbeda dengan pemahaman agama pada level orang dewasa.

Konsep yang akan dipaparkan akan menjelaskan bahwa "rasa akan agama"akan berbeda dengan pemahaman akan pengetahuan agama. Saat pengetahuan agama akan menjelaskan tentang informasi tentang agama yang bersumber dari kitab suci, sedangkan "rasa akan agama" terkait dengan sebuah intisari dari sebuah pengetahuan dari kitab suci tadi. Namun apabila anak-anak belum memiliki rasa dalam beragama maka belum tentu disebabkan anak tersebut belum memiliki pengetahuan yang cukup akan ajaran sebuah agama. Menurut Zakiah Daradjat, anak-anak sudah akan memiiki rasa akan beragama melalui perkembangan bahasa yang telah diucapkan orang tua atau orang dewasa yang ada di lingkungannya. ${ }^{28}$

Anak-anak khususnya anak usia dini belum bisa menelaah sebuah konsep yang terlalu abstrak dalam agama seperti siapa Allah? Bagaimana Allah ada?. Oleh karena itu konsep agama bagi anak usia dini khususnya hendaklah selalu dipersepsikan sebagai hal yang konkrit agar anak bisa menjangkaunya. Melalui pemahaman tersebut, akan dipahami bersama bahwa pemahaman serta pemaknaan agama pada anak akan meningkat seiring dengan perkembangan usianya. Anak akan mulai mencari tahu secara pelan-pelan tentang agamanya dan mulai ingin berinteraksi serta berkomunikasi dengan Allah. Bagi anak yang orang tuanya beragama Islam akan memaknai berkomunikasi dengan Allah melalui "doa" yang secara konkrit dilakukan melalui mengangkat kedua tangannya ke atas. Oleh karena itu, konsep agama sebagai pemberi rasa aman, penuh kasih sayang serta memberi perlindungan adalah sebuah konsep agama yang bisa dipersepsikan oleh anak sesuai dengan tahap perkembangan usianya. Makna agama bagi anak-anak adalah sesuatu yang bersifat konkrit dan jauh lebih kuat daripada dirinya sehingga mampu memberikan perlindungan, rasa aman dan kasih sayang.

\section{Munculnya Rasa Beragama Pada Anak}

Pemahaman nilai agama pada diri anak berawal pada perkembangan bahasa yang telah ia dapatkan dari lingkungan sosialnya. Pada awal perkembangannya, mungkin anak masih belum bisa mengikuti dikarenakan belum memiliki pengalaman empiris atas "rasa agama" itu tadi. Namun seiring dengan perkembangannya, anak mulai menaruh perhatian pada agama bersamaan dengan mulai banyaknya pengalaman empiris anak dalam beragama seperti menyaksikan orang tuanya sholat, puasa atau kegiatan ritual agama lainnya.

Pada prosesnya anak mungkin bisa mengasumsikan kalau konsep agama atau Allah sebagai sosok yang "jahat" karena jika seseorang tidak sholat maka Allah akan marah atau Allah akan memberikan hukuman di neraka kelak. Kondisi ini pada akhirnya akan membuat anak tidak nyaman dan merasa tertekan jika tidak melakukan kegiatan

28 Suyadi Suyadi, Psikologi Belajar PAUD (Yogyakarta: Pedagogia, 2010). 125 
ibadah. Namun sebenarnya ketakutan anak ataupun penolakan anak itu merupakan hal yang wajar. Saat ketakutan tersebut semakin ditekan maka akan semakin mempengaruhi anak tersebut.

Sebagaimana Freud mengatakan bahwa saat seseorang mengingkari kenyataan yang menyakitkan hati maka hal tersebut merupakan fase pertengahan yakni antara menerima dan menerima. ${ }^{29}$ Oleh karena itu, semakin kuat seorang anak menolak konsep agama maka akan semakin kuat pula potensi mereka untuk menerimanya. Pada saat seperti itulah persepsi tentang agama itu baik, Allah itu maha penolong, Allah Maha pengampun dll bisa dihadirkan kepada anak. Harapannya adalah hati anak akan menjadi tenang dan akan memunculkan kecintaan dan keinginan untuk terus berkomunikasi dengan Allah. Dengan demikian, cara memunculkan rasa beragama pada anak adalah dimulai dengan pemberian stimulasi dari luar (komunikasi/ bahasa) yang akan mempengaruhinya dan kemudian untuk diterima anak setelah sebelumnya berusaha untuk diingkari oleh sang anak.

Pada masa perkembangan anak usia dini, memunculkan rasa beragama pada anak hendaklah sesuai dengan tingkat pemahaman anak. Keselarasan antara pola pendidikan juga menjadi hal yang penting, terutama pengembangan bahasa dan pola pikir di lingkungan keluarga serta lembaga sekolah anak usia dini. Jika pola pendidikan di rumah dan di sekolah mempertimbangkan faktor perkembangan ini maka anak akan menjadi individu dengan pemahaman agama yang konsisten dan menerima keberagaman yang ada. Tinjuan akhirnya adalah muncul rasa beragama yang menyeluruh pada anak usia dini.

\section{Tahap-tahap Perkembangan Nilai, Moral dan Keagamaan pada Anak Usia Dini}

Dalam konteks perkembangan nilai, oral dan keagamaan, terdapat beberapa tahaptahap perkembangan moral yang sangat terkenal yakni teori yang dikemukaan oleh John Dewey yang selanjutnya dikembangkan oleh Jean Piaget dan Lawrence Kohlberg. Tahaptahap perkembangan moral sesuai dengan pandangan masing-masing tokoh sebagaimana akan dijelaskan secara umum.

John Dewey mengemukakan tiga tahapan perkembangan yaitu: ${ }^{30}$

a. Tahap Pra-moral

Ini ditandai bahwa anak belum menyadari keterikatannya pada aturan

b. Tahap Konvensional

Ini ditandainya dengan berkembangnya kesadaran akan ketaatan pada kekuasaan

c. Tahap Otonom

Ini ditandainya dengan berkembangnya keterikatan pada aturan yang didasarkan pada hubungan timbal balik

Adapun tahap-tahap perkembangan moral yang sangat terkenal adalah teori yang dikemukakan oleh Lawrence Kohlberg yaitu: ${ }^{31}$

a. Tahap Prakonvensional

${ }^{29}$ Sigmund Freud, Pengantar Umum Psikoloanalisis, (Yogyakarta: Pustaka Pelajar, 2006). 283

${ }^{30}$ Asrori, Psikologi Pembelajaran. 156

${ }^{31}$ John W Santrock, Life Span Development (New York: Mc. Graw-Hill, 2004). 341 
Pada tahap ini anak tanggap pada aturan-aturan budaya dan ungkapan-ungkapan budaya mengenai baik dan buruk serta benar dan salah. Namun semua ini akan ditafsirkan oleh sebab akibat fisik atau atas perbuatan yang telah dilakukan seperti:adanya hukuman, keuntungan karena telah melakukan hal baik atau bahkan mekanisme pertukaran atas sesuatu atas dasar untung dan rugi. Tahap prakonvensional memiliki dua tahap yaitu :

Tahap 1 : Orientasi hukuman dan kepatuhan

Pada tahap ini, akibat-akibat fisik suatu perbuatan menentukan baik buruknya dari apa yang telah dilakukan. Anak semata-mata hanya berusaha menghindari hukuman dan akan patuh pada kekuasaan tanpa mempersoalkannya

Tahap 2: Orientasi relatif instrumental

Pada tahap ini, setiap perbuatan yang dianggap benar adalah perbuatan yang merupakan alat untuk memenuhi kebutuhannya sendiri dan adang-kadang juga untuk kebutuhan orang lain. Hubungan dengan orang lain terjalin dikarenakan adanya hubungan timbal balik atas dasar untung dan rugi.

b. Tahap Konvensional

Pada tahap ini anak akan menuruti keinginan dari keluarga dan lingkungan. Semua hal akan dipandang sebagai hal yang akan bernilai kesenangan pada orang lain. Sikap anak bukan hanya bersifat konformitas atas sekelilingnya namun juga sebagai pribadi. Anak akan loyal dan secara aktif akan mempertahankan, mendukung dan membenanrkan seluruh aturan. Tujuannya adalah untuk mengidentifikasikan dirinya dengan orang lain atau kelompok yang terkait. Tingkat konvensional memiliki dua tahap yaitu :

Tahap 3: Orientasi kesepakatan antara pribadi

Pada tahap ini akan muncul istilah "anak manis" yang merupakan sebuah pandangan dari lingkungan atas sebuah perilaku anak yang telah dilakukan dan dipandang baik dan menyenangkan orang lain. Artinya konsep benar dan salah akan ditentukan perbuatan anak berdasarkan penilaian lingkungannya. Anak akan melakukan banyak persamaan dengan suatu hal yang dilakukan oleh orang lain dengan harapan bisa menjadi anak yang baik.

Tahap 4 : Orientasi hukum dan ketertiban

Pada tahap ini, terdapat orientasi terhadap otoritas, aturan yang tetap dan menjaga sebuah ketertiban sosial yang ada. Perilaku anak yang dianggap baik adalah perilaku yang bisa menjaga tatanan sosial dan ketertiban yang telah terjalin.

\section{c. Tahap Post-konvensional}

Pada tahap ini terdapat usaha untuk merumuskan nilai-nilai dan prinsip-prinsip moral yang memiliki keabsahan dan dapat dapat diterapkan. Artinya anak diajak untuk menentukan suatu perilaku dengan berpegang pada prinsip-prinsip yang telah ada tanpa harus indentifikasi diri terhadap kelompok tersebut Tahap postkonvensional memiliki dua tahap yaitu : 
Tahap 5 : Orientasi kontrak sosial

Pada tahap ini, perbuatan yang baik cenderung dirumuskan dalam kerangka hak dan ukuran umum yang telah diuji secara kritis dan telah disepakati oleh masyarakat. terdapat suatu penekanan atas prosedural untuk mencari kesepakatan dan hak adalah masalah "nilai" dan "pedapat" pribadi. Artinya penekanan terdapat pada sudut pandang legalitas, tetapi dengan penekanan pada kemungkinan untuk mengubah hukum berdasarkan pada pertimbangan rasional dan kebermanfaatan sosial.

Tahap 6 : Orientasi prinsip dan etika universal

Pada tahap ini, hak ditentukan oleh keputusan masing-masing sesuai dengan prinsip-prinsip etis yang telah dipilih. Prinsip-prinsip ini bersifat abstrak dan etis serta bukan merupakan peraturan moral nyata.

Piaget juga mengkaji perkembangan keagamaan pada anak dengan pendekatan moral-kognitif. Piaget membandingkan perbandingan antara kognitif anak-anak dengan orang dewasa dan ditemukan bahwa perkembangan kognitif merpakan dasar bagi perkembangan moral. Namun Piaget masih ragu apakah perkembangan moral bisa menjadi dasar bagi perkembangan agama pada anak-anak. Oleh karena itu Piaget hanya berharap kalau pendekatan moral kognitif yang dikemukakannya akan memiliki korelasi paralel dengan perkembangan agama. ${ }^{32}$

Piaget mengemukakan ada dua tahapan dalalm perkembangan moral, yaitu tahap moral realisme dan tahap moral kemerdekaan. Piaget mempertanggungjawabkan kedua tahapan moral tersebut melalui cerita atau kisah baik dan buruk. Kemudian anak akan diminta untuk mengungkapkan nilai benar atau adalah atas cerita yang sudah dipaparkan sebelumnya. ${ }^{33}$ Kedua tahap perkembangan moral ini dimaksudkan agar anak-anak dapat menafsirkan agama secara konkrit (benar-salah). Hanya dengan pemahaman yang konkrit seperti itulah anak-anak dapat menilai moralitas dalam agama secara lebih konspetual dan abstrak.

Secara umum, tahapan perkembangan moral yang dikemukakan oleh Kohlberg dan Piaget masih membahas dalam tataran dimensi moral secara umum. Namun David Elkind mencoba mengembangkan teori Piaget kedalam pola keagamaan pada anak.

Elkind mengemukakan ada empat tipe kebutuhan yang akan muncul ketika anak akan tumbuh ke arah dewasa, yaitu: ${ }^{34}$

a. Tahap Konservasi

Pada tahap ini anak-anak memiliki ketetapan sebagai obyek yang mempunyai kekurangan . pada tahap ini anak-anak hidupnya adalah selamanya.

b. Tahap Reprensentasi

Pada tahap ini dimulai pada tahap pra sekolah anak. Pada tahap ini yang dipentingkan adalah gamparan tentang pentingnya perkembangan mental dan bahasa pada anak.

32 Suyadi, Psikologi Belajar PAUD. 131

33 Raymond F. Paloutzian, Invitation To Psychology Of Religion (Boston: Allyn Bacon, 1996). 90

${ }^{34}$ Ibid. 91 
c. Tahap Relasi

Pada tahap ini anaksudah mengalami kematangan mental sehingga sudah bisa merasakan pentingnya untuk mberhubungan dengan agamanya atau konsep keTuhanan yang dimiliknya.

d. Tahap Pemahaman

Pada tahap ini anak-anak berada dalam tahapan menuju kedewasaan. Anak-anak akan memaknai sebuah konsep tetantang pentingnya keberadaannya di lingkungan seperti pemahaman konsep bersahabat atau menjalin hubungan dengan orang lain.

Berbeda dengan Elkind, Harms mengemukakan bahwa terdapat tiga perkembangan beragama pada anak yaitu :35

a. Tahap fairytale (usia 3-6 tahun)

Pada tahap ini anak mempresentasikan keadaan Tuhan seperti serupa raksasa, hantu, malaikat bersayap dll

b. Tahap realistis (7-12 tahun)

Pada tahap ini anak cenderung akan mengonkretkan agama. Anak akan mempersepsikan Tuhan dan simbol agama sebagai penampakan yang nyata yang memiliki pengaruh pada kehiduoan di dunia

c. Tahap individualistik (13-18 tahun)

Pada tahap ini anak cenderung akan menentukan pilihan dan pemahaman atas agama dengan model dan persepsinya.

\section{Kesimpulan}

Pada proses pengembangan jiwa keagamaan dan moral anak usia dini harus mempertimbangkan tahapan perkembangannya anak, baik perkembangan psikis ataupun fisiknya. Ada anak usia dini yang cepat dalam memahami konsep-konsep agama, namun ada pula yang tergolong lamban dalam menangkap konsep tersebut. Mengembangkan jiwa keagamaan anak usia dini diwujudkan dalam bentuk keikutsertaan dalam kegiatan keagamaan sehari-hari, sehingga anak mendapatkan langsung pengalaman nyata yang diajarkan oleh orang tua ataupun guru. Metode penyampaian bisa melalui ceramah, permainan, cerita, bermain peran, pembiasaan dan keteladanan. Oleh karena itu baik orang tua dan guru perlu memberikan stimulasi agar anaknya bisa cepat dalam merespon pembelajaran konsep agama dengan harapan dapat menumbuh kembangkan rasa keberagamaannya.

\section{Daftar Rujukan}

Ananda, Rizki. “Implementasi Nilai-Nilai Moral Dan Agama Pada Anak Usia Dini.” Jurnal Obsesi: Jurnal Pendidikan Anak Usia Dini 1, no. 1 (2017): 19-31.

Asrori, Mohammad. Psikologi Pembelajaran. Bandung: CV . Wacana Prima, 2009.

Daradjat, Zakiah. Ilmu Pendidikan Islam. Jakarta: PT. Bumi Aksara, 2018.

\footnotetext{
${ }^{35}$ Suyadi, Psikologi Belajar PAUD. 133
} 
Desmita, Desmita. Psikologi Perkembangan. Bandung: PT. Remaja Rosdakarya, 2015.

Diadha, Rahminur. "Keterlibatan Orang Tua Dalam Pendidikan Anak Usia Dini Di Taman Kanak-Kanak." Edusentris 2, no. 1 (2015): 61-71.

Fatihudin, Didin. Metode Penelitian. Sidoarjo: Zifatama Publisher, 2015.

FN, Ainna Amalia, Asri Prasetyaningsih, Ari Kusuma Sulyandari, Ratih Permata Sari, Barratun Naqiyah, Mistria Harmonis, Triana Rosalina Noor, Novita Christy Rahayu, Siti Mudjaidah, and Putri Ismawati. Metode Pengembangan Kognitif Anak Usia Dini. Surabaya: UIN Sunan Ampel Press, 2018.

Freud, Sigmund. Pengantar Umum Psikoloanalisis, Yogyakarta: Pustaka Pelajar, 2006.

Hurlock, Elizabeth B. Perkembangan Anak Jilid 2. Jakarta: Erlangga, 1999.

Idrus, Muhammad. "Makna Agama Dan Budaya Bagi Orang Jawa." Unisia 30, no. 66 (2007): 391-401.

Jalaluddin, Jalaluddin. Pendidikan Islam :Pendekatan Sistem Dan Proses. Jakarta: PT. RajaGrafindo Persada, 2016.

———. Psikologi Agama. Jakarta: PT. RajaGrafindo Persada, 2012.

Kh, Elfan Fanhas F, and Gina Nurazizah Mukhlis. "Pendidikan Karakter Untuk Anak Usia Dini Menurut QS Lukman: 13-19.” PEDAGOGI: Jurnal Anak Usia Dini Dan Pendidikan Anak Usia Dini 3, no. 3a (2017): 42-51.

Noor, Triana Rosalina. "Analisis Desain Fasilitas Umum Bagi Penyandang Disabilitas (Sebuah Analisis Psikologi Lingkungan)." Journal An-Nafs: Kajian Penelitian Psikologi 2, no. 2 (2017): 133-150.

- - - "Manajemen Pendidikan Anak Melalui Program Outbound Di TK Al Muslim Surabaya." SELING: Jurnal Program Studi PGRA 3, no. 2 (2017): 64-75.

- - - "Orientasi Aktivitas Dan Kelompok Keagamaan Mahasiswa." In Prosiding Seminar Nasional Islam Moderat, 1:154-163. Jombang: Unwaha, 2018.

- - - "Remaja Dan Pemahaman Agama." Vicratina: Jurnal Pendidikan Islam 3, no. 2 (2019): 54-70.

- - - "Upaya Guru Dalam Menanamkan Nilai Agama Di KB Al Muslim Surabaya." EDUSIANA: Jurnal Manajemen dan Pendidikan Islam 4, no. 1 (2017): 65-82.

Noor, Triana Rosalina, and Erwin Astutik. "RODA (Rotating Education Game) Sebagai Media Pembelajaran Untuk Menanamkan Sikap Disiplin Pada Anak Usia Dini." ASSABIQUN 1, no. 2 (2019): 1-16.

Paloutzian, Raymond F. Invitation To Psychology Of Religion. Boston: Allyn Bacon, 1996.

Rahman, Mohamad Syakur. "PERAN ORANG TUA DALAM PENANAMAN NILAI-NILAI ISLAM." Jurnal Ilmiah Iqra' 12, no. 1 (2018): 14-34.

Rizky, Rafieqah Nalar, and Moulita Moulita. "PENANAMAN NILAI-NILAI ISLAM MELALUI 
KOMUNIKASI INTERPERSONAL ORANG TUA PADA ANAK." Jurnal Interaksi: Jurnal Ilmu Komunikasi 1, no. 2 (2017): 206-219.

Santrock, John W. Life Span Development. New York: Mc. Graw-Hill, 2004.

Saputra, Muhammad Ali. "Penanaman Nilai-Nilai Agama Pada Anak Usia Dini Di RA DDI Addariyah Kota Palopo." Al-Qalam 20, no. 2 (2016): 197-210.

Suyadi, Suyadi. Psikologi Belajar PAUD. Yogyakarta: Pedagogia, 2010.

Tafsir, Ahmad. Ilmu Pendidikan Dalam Perspektif Islam. Bandung: PT. Remaja Rosdakarya, 2014.

Yunalia, Endang Mei, and Arif Nurma Nurma Etika. "Analisis Perilaku Agresif Pada Remaja Di Sekolah Menengah Pertama." JHeS (Journal of Health Studies) 4, no. 1 (2020): 38-45. 